\title{
The History and Current Status of Dual-Career Families in Malaysia
}

\author{
R. Zaimah ${ }^{1}$, M. S. Sarmila ${ }^{1}$, S. Selvadurai ${ }^{1}$, N. Lyndon ${ }^{1}$, A. C. $\operatorname{Er}^{1} \&$ Muhd Norizam Jamian ${ }^{2}$ \\ ${ }^{1}$ School of Social, Development and Environmental Studies, Faculty of Social Sciences and Humanities, \\ Universiti Kebangsaan Malaysia, Malaysia \\ ${ }^{2}$ School of Malay Language, Literature and Culture, Faculty of Social Sciences and Humanities, Universiti \\ Kebangsaan Malaysia, Malaysia \\ Correspondence: R. Zaimah, School of Social, Development and Environmental Studies, Faculty of Social \\ Sciences and Humanities, Universiti Kebangsaan Malaysia, Bangi, Selangor, Malaysia. E-mail: \\ zaimahr@ukm.my
}

Received: March 14, 2013 Accepted: April 11, 2013 Online Published: April 28, 2013

doi:10.5539/ass.v9n6p16 URL: http://dx.doi.org/10.5539/ass.v9n6p16

\begin{abstract}
Dual-career families in Malaysia began with the influx of women into the workplace. The involvement of women in the labor market became more apparent after independence. In 1985, the Government of Malaysia formulated the National Policy on Women as a guide for women's participation in the development process. The stature of women became a primary objective of the 6th Malaysia Plan (1991-1995), where a special fund for the development of women became a significant and integral step towards empowering women in Malaysia. In fact, the number of dual-career families in Malaysia is expected to rise due to the increase in female labor force participation rate. Therefore, the main objective of this paper is to understand the phenomenon of dual-career families in Malaysia. This paper will focus on the participation of women in the labor force before independence, after independence and an update of its current situation.
\end{abstract}

Keywords: dual-career families, women's participation, labor force, occupation, education

\section{Introduction}

The last four decades have witnessed an increase in the employment level of women in most developing countries, including Malaysia. The economic development and growth in Malaysia during that time have created new employment opportunities benefiting both men and women. Increased access to the educational attainment of women has enabled them to be gainfully employed in all economic sectors such as manufacturing, business, service and agriculture, in addition to their traditional role in the unpaid domestic sector of the economy.

The involvement of women in the labor force is becoming a rising trend since Malaysia gained independence in 1957. In 1985, the Government of Malaysia formulated the National Policy for Women (NPW) as a guide for women's participation in the development process (Malaysia, 1986). Its overall objectives are to ensure equitable sharing in the acquisition of resources and information as well as access to opportunities and benefits of development, for both men and women; and to integrate women in all sectors of national development in line with their abilities and needs in order to improve the quality of life, eradicate poverty, abolish ignorance and illiteracy and ensure a peaceful and prosperous nation.

The stature of women became a primary objective of the 6th Malaysia Plan (1991-1995), where a special fund for the development of women became a significant and integral step towards empowering women in Malaysia (Malaysia, 1996). The female labor force continues to be an important component of the labor supply in Malaysia, accounting for 33.1 percent of the total labor force in 2000, 44.7 percent (year 2000), 45.7 percent (in 2005 ) and 46.4 percent (in 2009), and as has been documented, labor force participation rates among married women have increased in recent decades, rising from 58.6 percent in 2005 to 59.4 percent in 2009 (Malaysia $1991 ; 1996 ; 2001 ; 2006 ; 2010)$. Consequently, there has been an increase in the number of families with both husband and wife working, namely dual-earner family or dual-income family.

Dual-earner family means both spouses, husband and wife had income-producing jobs (Goldsmith, 2005; Winkler, 1998). Dual-earner families are also better educated, more mobile, better spenders, and more likely to own their home than single-earner families (Winkler, 1998). However in dual-career families, not only do both spouses work outside the home, but in addition, both have made a long-term commitment to a planned series of 
jobs leading towards an ultimate career goal (Goldsmith, 2005). The term 'dual-career families' was coined to designate a type of family structure in which both heads of household, the husband and wife, pursue active careers and family lives (Rapoport \& Rapoport, 1977). Career is sometimes used to indicate any sequence of jobs, but in its more precise meaning it designates those types of job sequences that require a high degree of commitment that have a continuous character development. In short, dual-career families represent a special type of dual-worker family that begins with the involvement of women in the employment sector. Therefore, this paper will focus on the participation of women in the labor in the period of pre and post independence and provides an update of its current situation that contribute to the emergence of dual-career family in the nation.

\section{Methodology}

Data for this study were gathered, compiled and calculated from various secondary sources. The sources included reports from government departments, ministries, and individual researchers. Trends data for labor force participation and employment were obtained from the national population census reports which incorporated data gathered every ten year period by the Department of Statistics. The trend data were also compiled from annual reports of the Ministry of Human Resources and the government five-year plan reports. The trend data compiled by individual researchers were also used. For trend analysis, the data selected were those available within the period between 1970 and 2005. In the process of compiling data within this period, there were instances whereby the presented data were in different forms. In such situation the researcher adapted the data through the calculation to arrive at uniform presentation.

\section{Women Participation in the Labor Force}

The participation of women in the labor force has been on a rising trend since Malaysia gained independence in 1957. They engage in paid employment in all the economic sectors as an employer, self-employed and also unpaid family workers. Changes have been occurring in the employment pattern of women during the period 1957-2010 in line with a changing economic structure that saw the country transforming itself from an agriculture-based economy to the manufacturing sector, and also to the services sector (Malaysia, 1991; 1996; $2001 ; 2006 ; 2010)$.

\subsection{Women and Occupation: Before Independence}

The change in economic development of Malaysia from the traditional sector to the modern sector has brought many changes to the pattern of womens' participation in economic activities. Table 1 shows that, almost 51 percent of women were engaged in paddy cultivation as compared to 49.1 percent of men.

Table 1. Population engaged in agriculture, Malaya in 1911 and 1957

\begin{tabular}{lrrrr}
\hline \multicolumn{1}{c}{ Activities } & \multicolumn{2}{c}{1911} & \multicolumn{2}{c}{1957} \\
& \multicolumn{1}{c}{ Male } & \multicolumn{1}{c}{ Female } & \multicolumn{1}{c}{ Male } & \multicolumn{1}{c}{ Female } \\
\hline Paddy cultivation & $53,795(49.1 \%)$ & $55,679(50.9 \%)$ & $264,895(65.5 \%)$ & $133,400(33.5 \%)$ \\
Fishery & $6,216(97.2 \%)$ & $177(2.8 \%)$ & $60,669(98.8 \%)$ & $762(1.2 \%)$ \\
Mining & $156,327(95.3 \%)$ & $7,353(4.5 \%)$ & $49,026(83.8 \%)$ & $9,473(12.2 \%)$ \\
Commercial crops & $5,551(90.6 \%)$ & $471(9.4 \%)$ & $428,134(64.0 \%)$ & $239,313(35.9 \%)$ \\
\hline
\end{tabular}

Source: Nor Aini, Madeline and Faridah (1996)

However, in 1957, the percentage of men engaged in paddy cultivation increased to 66.5 percent, while the percentage of women declined to 33.5 percent. On the other hand, the percentage of women engaged in commercial crop in 1957 are also quite significant, compared to mining and fisheries sectors, which is dominated by men.

\subsection{Women and Occupation: After Independence until Year 2000}

The increasing importance of women in the labor force in Malaysia can be analyzed in relation to he new development in the world economic linked to export-oriented industrialization (Zaimah \& Sarmila, 2004). In 1970, females accounted for 32 percent of the total labor force in Malaysia although 50 percent of them were in the working-age group. In terms of educational attainment the female labor force has become more educated since 1957, with 16.7 percent of them having acquired tertiary education while 51.9 percent had passed their secondary education. 
The participation rate of women has shown an increasing trend during the period 1970-2000 as shown in Table 2 . The labor force participation rate for women increased from 37.2 percent in 1970 to 46.7 percent in 1990. Their participation rate, however, continued to lag behind that of men who registered rates of 81.3 percent and 85.6 percent over the same period (Malaysia, 1991).

Table 2. Employment distribution by occupation and sex, 1970-2000

\begin{tabular}{crrrrrrrrrrrrr}
\hline Occupational & \multicolumn{1}{c}{1970} & \multicolumn{3}{c}{1980} & \multicolumn{1}{c}{1985} & \multicolumn{1}{c}{1990} & \multicolumn{3}{c}{1995} \\
Category & $M$ & $F$ & $M$ & $F$ & $M$ & $F$ & $M$ & $F$ & $M$ & $F$ & $M$ & $F$ \\
\hline A & 4.6 & 5.3 & 6.4 & 8.5 & 6.8 & 9.1 & 6.4 & 9.4 & 8.4 & 13.5 & 8.9 & 13.5 \\
B & 1.0 & 0.1 & 1.4 & 0.3 & 3.2 & 0.6 & 2.8 & 0.6 & 4.4 & 1.9 & 4.7 & 2.2 \\
C & 5.4 & 4.1 & 6.8 & 11.1 & 7.4 & 14.2 & 7.0 & 14.1 & 7.3 & 17.6 & 7.1 & 17.5 \\
D & 9.8 & 4.9 & 10.3 & 7.2 & 11.1 & 11.0 & 11.4 & 11.4 & 10.9 & 11.3 & 11.1 & 12.1 \\
E & 8.1 & 8.4 & 9.0 & 9.0 & 10.1 & 13.7 & 9.9 & 14.1 & 9.9 & 13.4 & 9.5 & 17.4 \\
F & 47.6 & 66.8 & 35.9 & 46.3 & 28.7 & 33.7 & 29.4 & 28.1 & 20.9 & 15.8 & 20.4 & 14.8 \\
G & 23.5 & 10.4 & 30.2 & 17.6 & 32.7 & 17.7 & 33.1 & 22.3 & 38.2 & 26.5 & 38.4 & 22.6 \\
Total & 100 & 100 & 100 & 100 & 100 & 100 & 100 & 100 & 100 & 100 & 100 & 100 \\
\hline
\end{tabular}

Source: Compiled from Malaysian Plan, 1970-2001

Note: $M=$ male, $F=$ female

A $=$ Profesional, Technical \& Related workers

$\mathrm{B}=$ Administrative \& Managerial Workers

$\mathrm{C}=$ Clerical \& Related Workers

$\mathrm{D}=$ Sales \& Related Workers

$\mathrm{E}=$ Service Workers

$\mathrm{F}=$ Agricultural Workers

$\mathrm{G}=$ Production \& Related Workers

The employment trends reflected a similar pattern for both males and females. While the average percentage distribution of men decreased from 69 percent to 65 percent between 1970 and 1990, the percentage distribution of women increased from 31 percent to 35 percent during the same period. The overall female employment remained low compared to male, largely attributable to the lack of appropriate skills and competing demands of the home.

The proportion of women as unpaid family workers in the traditional and informal sectors fell from 39.7 percent in 1970 to 21.6 percent in 1990 . The decline was largely due to the absorption of this group of women into the modern sectors, particularly the estate subsector and the industrial and services sectors. Consequently, the proportion classified as employee rose from 38.9 percent to 62.9 percent during the same period, indicating the growing significance of formal female employment.

In terms of the occupational structure, women were largely concentrated on low-skilled, labor-intensive jobs in the agriculture sector and in low-paying, semi-skilled, assembly-type production operations in the industrial sectors, as illustrated in Table 2. In 1990, even though 9.4 percent of women were in professional and technical occupations, the majority of them were in teaching and nursing. Their participation in administrative and managerial occupation was also less than 1 percent.

The number of women employed during the Seventh Plan period (1996-2000) increased from 31.4 percent of total employed in 1990 to an estimated 33.7 percent in 1995. An interesting trend observed during the period was the decline in the proportion of women relative to men in working the primary and secondary sectors, and the progressive increase in their participation in the tertiary sector, particularly the distributive trade and financial sectors (Malaysia, 1996). However, the manufacturing sector continued to absorb the largest share of employed women. 
In terms of occupational structure, women made advances into higher-paying occupations during the period. The proportion of women in the professional and technical as well as the administrative and managerial occupational categories increased significantly from 9.4 percent and 0.6 percent in 1990 to 13.5 percent and 1.9 percent in 1995 (Table 2). Women were mainly employed as production and related workers, accounting for 26.5 percent of total female employment. The ratio of women employed as agricultural workers declined in line with the weakening prospect for employment in the sector.

\subsection{Women and Occupation: Current Situation, 2000 and Thereafter}

During the Eight Plan period (2001-2005), the female labor force participation rate continued to increase from 44.7 percent in 2000 to 45.7 percent in 2005 . The number of women employed during the period increased from 3.3 million in 2000 to 3.9 million in 2005 (Malaysia, 2006). In terms of occupational structure, a higher percentage of women employed in high-paying occupation, were mainly due to improvements in their educational attainment (http://www.unicef.org). This is obviously seen from the proportion of women in the senior officials and managers category that increased from 4.8 percent in 2000 to 5.4 percent in 2005 (Table 3).

Table 3. Employment by occupation and gender, 2000-2005

\begin{tabular}{lrrrr}
\hline \multicolumn{1}{c}{ Occupational Category } & & 2000 & & 2005 \\
& Male & Female & Male & Female \\
\hline Senior Officials and Managers & 8.0 & 4.8 & 9.4 & 5.4 \\
Professional & 5.1 & 7.2 & 5.5 & 7.5 \\
Technicians \& Associate Professionals & 10.9 & 14.1 & 12.6 & 14.0 \\
Clerical Workers & 5.2 & 18.3 & 4.6 & 17.2 \\
Services and Sales Workers & 12.9 & 13.3 & 12.3 & 17.7 \\
Skilled Agricultural and Fishery Workers & 17.5 & 10.0 & 14.7 & 9.9 \\
Craft and Related Trade Workers & 11.5 & 4.4 & 15.2 & 5.0 \\
Plant and Machine Operators and Assembkers & 16.2 & 15.8 & 15.9 & 11.5 \\
Elementary Occupations & 12.7 & 12.1 & 9.8 & 11.8 \\
Total & 100.0 & 100.0 & 100.0 & 100.0 \\
\hline
\end{tabular}

Source: Compiled from Malaysian Plan, 2001-2010

In the professional category, women were mainly employed as a doctor, dentist, lawyers and architects. A significant increase was also recorded in the services and sales worker category from 13.3 percent in 2000 to 17.7 percent in 2005 while the share of women in low-paying occupations declined, particularly in the plant and machinery operators and assemblers category (Malaysia, 2006).

With the growing female population from 11.5 million in 2000 to 13.9 million in 2009 , women continue to be a primary force in influencing the development of future generations and contributing to the economy. The participation rate of women in the labor force also increased from 44.7 percent in 1995 to 45.7 percent in 2008 , and the number further improved to 46.4 percent in 2009 (Malaysia, 2010).

Finally, as referred to the Ninth Plan (2011-2015), empowerment of women will be a key agenda in this Plan, where the Government will increase its efforts towards addressing issues confronting women to enable them realize their full potential and participate more effectively in the economic and social development of the country Malaysia (Malaysia, 2006). The Economic Planning Unit, Prime Minister's Department, Putrajaya. As such, this will contribute to the increase in the number of dual-career families in Malaysia.

\section{Women and Education}

One of the most important factors that contributed to the increase in employment rates for females is the expansion of educational facilities across the country coupled with the increased of value attached to education. The opportunities and accessibility in education among women in Malaysia are driving the increase of their participation in the labor force (Sabitha, 2005; Jamilah, 2001; Aminah, 1998). Hence, this situation has led to the creation of dual-income families and dual-career in Malaysia. 
The achievement of women in formal education has been remarkable since independence as seen by the steady increase in participation rate at the primary, secondary and tertiary levels. Women have benefited to a large extent from the expansions of education facilities and the provision of increased educational opportunities.

Women benefited from equal access to educational opportunities as shown by the enrollment rates of male and female students at the primary and secondary levels of education. Gender differentiation was, nevertheless, apparent by the preference of female students for non-technical and non-vocational disciplines. However, over the 1970-1990 periods, female enrollment in the technical stream increased markedly from 4.3 percent to 35.9 percent.

The female intake into universities constituted about 44 percent of the total intake during the Fifth Plan period (1986-1990), with female students making increasing inroads into areas like medicine, dentistry, engineering, architecture and accountancy. Although more female students enrolled in science and technology courses, there continued to be a preponderance of female students in the arts and applied arts courses.

In the Sixth Plan period (1991-1995), women continued to receive equal access to educational opportunities, a factor which has contributed to their economic and social advancement. Female enrollment at the primary and secondary levels was about half of total enrollment, while at the upper secondary level, female students accounted for about 52.3 percent of total enrollment. The female intake into universities expanded rapidly from 37.2 percent in 1990 to 49.5 percent in 1994.

The improved educational status of women was reflected in higher educational attainment of the female labor force. For instance, the proportion of the female labor force with secondary and tertiary education was about 50 percent and 11 percent, respectively, in 1993 compared with 45.1 percent and 9.9 percent, respectively, in 1990. In contrast, the proportion of the female labor force with no formal education or primary education dropped from 15.7 percent and 29.3 percent, respectively, in 1990 to 12.6 percent and 26.4 percent, respectively, in 1993.

During the Seventh Plan period (1996-2000), enrollment of female student was about half of the total enrollment at the primary and secondary levels. While at the upper secondary level, female students accounted for about 66 percent of total enrollment in 2000. Intake of female students into public universities expanded significantly from 50 percent in 1995 to 55 percent in 2000.

In addition, the enrollment of female in the primary and secondary schools reflected the gender ratio in the country, accounting for about half of the total enrollment in 2005. Women enrollment at the matriculation and form six levels accounted for 67 percent while their enrollment in public universities continued to increase significantly from 61 percent in 2000 to 63.4 percent in 2005.

However, at the post-graduate level, female students accounted for only 48.8 percent and 35.7 percent for the masters and doctorate levels, respectively. Recently, women account for 65.9 percent of post secondary student enrollment in government assisted schools, as well as approximately 62.3 percent of enrollment in the first degrees in public higher learning institution in 2008 (Malaysia, 2006; http://www.unicef.org).

\section{Conclusion}

Malaysian women have achieved great progress in terms of their participation in economic activities during the past four decades. The expanding educational opportunities in the country mean that more avenues are available for women to develop the necessary skills and competencies necessary for their economic participation (Malaysia, 1991; 1996; 2001; 2006; 2010).

Since independence, with greater access to education, Malaysian women have progressed remarkably as economic participants, in line with the direction of the country's economic development. In the early years after independence, the opportunity for post secondary education was limited. Once the tertiary education facilities expanded rapidly during post-1970 period, the enrollment of women in tertiary education also rose. The educational opportunities encouraged the participation of women in highly skilled jobs and professions. Thus, it creates dual-career family structure in Malaysia. In addition, the existence of dual-career families also raises several issues, such as changes in gender roles, marital conflict, partnership and family financial decisions.

In short, the women's participation in the labor force is creating dual-career families, and given a lot of impact on family life. In the macro context, their participation has increased the employment rates and productivity of the country. Whereas in the micro context, it contributes to the improvement of economic and quality of life of the family. However, the participation of women in employment also increased family expenses such as food and drink outside the home, the cost of child care and transportation costs. 


\section{Acknowledgments}

The authors would like to thank Universiti Kebangsaan Malaysia for UKM-DLP-2012-030 under the leadership of the Assoc. Prof. Dr. Er Ah Choy.

\section{References}

Ahmad, A. (1998). Country Briefing Paper: Women in Malaysia. Retrieved May 5, 2010, from http://www.adb.org/document/books/country_briefing_paper/women_in_malaysia/women_malaysia.pdf

Ahmad, A. (1999). Participation of Malaysian women in employment: a gender stratification analysis. In M. Ismail, \& A. Ahmad (Eds.), Women and work: challenges in industrializing nations (pp. 1-25). London: Asean Academic Press.

Ariffin, J. (2001). The Changing Malaysian Family: Tracing Its Changes Through Trend Data and Research Findings. In J. Ariffin, \& A. Louis (Eds.), Family well-being: learning from the past for the betterment in the future (pp. 13-48). ISI Publication.

Dual-Earner Families. (2003). International Encyclopedia of Marriage and Family. Retrieved January 4, 2012, from http://www.encyclopedia.com/topic/Dual-Earner_Families.aspx

Goldsmith, E. B. (2005). Resource management for individuals and families. United States: Thomson Wadsworth.

Idris, N. A. H., Berma, M., \& Shahdan, F. (1996). Wanita Malaysia dalam era pembangunan industri. Bangi: Penerbit UKM.

Malaysia. (1986). The Fifth Malaysia Plan 1986-1990. Kuala Lumpur: Percetakan Nasional Berhad.

Malaysia. (1991). The Sixth Malaysia Plan 1991-1995. Kuala Lumpur: Percetakan Nasional Berhad.

Malaysia. (1996). The Seventh Malaysia Plan 1996-2000. Kuala Lumpur: Percetakan Nasional Berhad.

Malaysia. (2001). The Eighth Malaysia Plan 2001-2005. The Economic Planning Unit, Prime Minister's Department, Putrajaya.

Malaysia. (2006). The Ninth Malaysia Plan 2006-2010. The Economic Planning Unit, Prime Minister's Department, Putrajaya.

Malaysia. (2010). The Tenth Malaysia Plan 1996-2000. The Economic Planning Unit, Prime Minister's Department, Putrajaya.

Marican, S. (2005). Membentuk Suasana Kerja Positif: Aspek Hubungan Manusia dan Persekitaran Sosial. Kuala Lumpur: Utusan Publications \& Distributors.

Rapoport, R., \& Rapoport, R. N. (1976). Dual-Career Families Re-Examined. New York: Harper Colophon Books.

The progress of Malaysian women since independence 1957-2000. (2003). Ministry of Women and Family Development.

Retrieved

from http://www.utusan.com.my/utusan/SpecialCoverage/RMK9/english/Chapter13.pdf

UNICEF (n. d.). Women's participation in the workforce increasing. Retrieved February 25, 2012, from http://www.unicef.org/malaysia/sowc_6068.html

Winkler, A. E. (1998). Earnings of Husbands and Wives in Dual-Earner Families. Monthly Labor Review, 42-48.

Zaimah, R., \& Sarmila, M. S. (2004). Prestasi industri bukan berasaskan sumber dalam tempoh pelaksanaan Pelan Induk Perindustrian. In A. A. G. Hassan (Ed.), Prognosis Pembangunan \& Tranformasi Struktur. Sintok: Universiti Utara Malaysia. 